\title{
The Liberal Imagination in The Middle of the Journey
}

\author{
Christopher Phelps
}

When Lionel Trilling's first and only novel, The Middle of the Journey, was published in 1947, the circle of writers and cultural critics with whom he had long been associated was near the completion of its political transformation from anti-Stalinist radicalism to anti-communist liberalism. Only ten years before, most of these figures, yet to reach their self-anointed destiny as "the New York intellectuals," had been revolutionary socialists. Following a momentary association with Communism in the early thirties, they had become outspoken opponents of the bureaucratic despotism that had overtaken the global Communist movement, all the while upholding Marxism and retaining their opposition to imperialism and capitalism. By the late 1940s, however, a succession of international disasters - the Moscow trials, the Hitler-Stalin pact, the Second World War and the emergent Cold War, as well as the toll exacted over time by the condition of marginality to which revolutionary anti-Stalinists were relegated - had unmoored the New York intellectuals, with few exceptions, from their commitment to the liberation of the working class and the abolition of capitalism. The Middle of the Journey appeared at that unique moment in postwar intellectual history when the New York intellectuals' attachment to revolutionary aims had been severed but their ultimate course was not yet altogether fixed.

If the mid-1940s were somewhat fluid, by the early 1950s the New York intellectuals were the practitioners of a suave, disappointed liberalism. Although they continued to refer to themselves as the "anti-Stalinist left," or part of it, their politics became ever more narrowly liberal as they ceased to distinguish between the worldview of Marxism, or the social ideal of communism, and the reality of Stalinism. This new sensibility, by which the New York intellectuals were reconciled, more or less consciously, to the social order they had once sought to abolish, meant that not just bureaucratic Communism but the whole spectrum of radical viewpoints, including the Marxism they themselves had espoused in the thirties, became in their minds suspect and sinister. This Cold War liberalism had much in common with New Deal reformism, but it was for the New York intellectuals defined mainly by moral disposition and intellectual style, not policy measures or 


\section{2 left history}

electoral commitments. Its élan of sophistication and open-endedness permitted the new liberalism's adherents to judge themselves free from ideology, beyond the ritualisms of left and right, and devoted in thought to the deliberate assessment of changing experience, not stagnant dogmas. ${ }^{1}$

Because The Middle of the Journey adroitly captured the dominant themes and dilemmas of this collective odyssey in a psychologically complex fictional narrative, Lionel Trilling (1905-1975) gave voice as much as any other New York intellectual in the immediate post-war years to the temperament of the deradicalizing circle. A close reading of the novel shows that The Middle of the Journey is best comprehended as a precisely executed literary justification of the wider political and intellectual transformation of the New York intellectuals. Its topical quality did not stem, for the most part, from any direct connection to Trilling's life or friendships. The book should not, for instance, be taken as a fictional account of the infamous Hiss-Chambers case, which erupted not long after the novel's appearance and invited speculation that Gifford Maxim and Arthur Croom were patterned upon Whittaker Chambers and Alger Hiss, respectively. ${ }^{2}$ As a novel of ideas in the broadest sense of the word, The Middle of the Journey cannot be reduced to any set of

1 There were exceptions to this pattern, as some went over to the right and a few remained on the left. On the whole, though, the move by 1950 was to Cold War liberalism. The late 1930s and 1940s were thus the moment of the first important political reorientation of the New York intellectuals. Many underwent a second transformation between the $1960 \mathrm{~s}$ and the 1980 s, abandoning a muted liberalism for an even more craven accommodation to the status quo. Trilling's position in this subsequent phase of the New York intellectuals' movement led the radical philosopher Cornel West to dub him the "godfather of neoconservatism." Neo-conservative writer William Barrett also thought of Trilling as the move-ment's forerunner, but it is the "firmest belief" of Diana Trilling that her husband "would never have become a neo-conservative and that, indeed, he would have spoken out against this outcome of the anti-Communist position." Cornel West, "Lionel Trilling: Godfather of NeoConservatism," New Politics 1 (Summer 1986), 233-42; William Barrett. The Truants: Adventures Among the Intellectuals (Garden City 1982), 168-9; Diana Trilling, The Beginning of the Journey, 404

2 In his 1975 introduction to a new edition of the novel, Trilling acknowledged that he had modeled Maxim on Chambers, his old Columbia University schoolmate, but denied any privileged knowledge of the famous espionage case. Though Trilling never even met Hiss before creating the character of Croom, the parallels between them are striking. Both the fictional Croom and the actual Hiss were sophisticated, ambitious, up-and-coming liberals; fellow-travelers sympathetic to the Soviet Union; administrators with bright prospects in Washington. Even a literary case may be made for their identity; the first names Alger and Arthur are similar, and there are double letters in both Croom and Hiss. Yet Trilling insisted that he had not even known of Hiss at the time of the novel's writing. Croom, he wrote, was a composite of several different figures meant to typify the fellow-traveller. See

"Introduction," The Middle of the Journey (New York 1975), vii-xxv. All further pages cited from the novel are placed in brackets in the text. 
simple referents in Trilling's life. Its significance lay in the import and currency of the intellectual themes it explored. ${ }^{3}$

Most reviews of the novel at the time of its release in October 1947 took it, with relative accuracy, to be a novel of the recent past, concerned with the liberal predicaments of the thirties. The reviews, if mixed, were on the whole very favorable. "With an intense impressionability he has looked at the social commitments of the individual through the deep, unknown motives operating within the self," wrote Wylie Sypher in Partisan Review, who averred that Trilling "has carried the liberal mind deep within the imagination." In The New York Times Book Review, Mark Schorer admired The Middle of the Journey for its "confidence in its own best qualities, literacy and intelligence, and the lucidity which is the consequence of these, and the rare grace with which it does precisely what it wishes to do." The reviewer for The Nation, Morton Dauwen Zabel, noted the novel's stylistic austerity and lack of action but observed that "as we read we lose our sense of lacking familiar fictional ingredients" and "become profoundly absorbed in the story," leading Zabel to conclude that Trilling's novel "is a brilliant example of a new mode of fiction, one whose function in the moral dilemmas of our age his acute critical sense has seen, and whose claims on the imaginative resources of his generation the finely controlled, humanly faithful art of this novel demonstrates." Time, on the other hand, sniffed that Trilling was "not yet a finished novelist," and J.M. Lalley in The New Yorker anticipated that, though the book would "receive a wide and favorable reading," many readers would be perplexed by "a few of the subtleties of Mr. Trilling's technique." In The New Republic, George Mayberry found the influence of Henry James and E.M. Forster (as well as the attempt at Arnoldian "high seriousness") "too plain," but he emphasized that "Trilling's novel is so far above the general level of recent fiction that these reservations are not those that would apply to any discussion of what now passes for literature." Insofar as reviewers criticized the novel, that is, it was

3 Mark Shechner, whose chapter on Trilling in After the Revolution (1987) contains the best critical treatment of The Middle of the Journey, writes, "Though the political moment in The Middle of the Journey is the late thirties, the book otherwise is a typical product of the mid forties." This goes half the needed distance. The political uncertainty and crystallizing liberalism of the New York intellectuals in the mid-forties - that is, the period's political moment, not just its mood and culture - is equally decisive. See Mark Shechner, After the Revolution: Studies in the Contemporary Jewish American Imagination (Bloomington 1987), 77.

4 Several other reviews are noteworthy: The New York Herald Tribune Weekly Book Review called The Middle of the Journey "both moving and intellectually provocative," Commonweal praised the writing as demonstrative of "high intelligence and peculiar tact," and The Saturday Review of Literature hailed Trilling's book as a "mature and intelligent novel." See: Wylie Sypher, "The Political Imagination," Partisan Review 15.1 (Jan. 1948), 123-7; Mark Schorer, "The Vexing Problem of Orientation," New York Times Book Review (12 Oct 1947), 4, 40; Morton Dauwen Zabel, "The Straight Way Lost," The Nation 
found emotionally and aesthetically - not intellectually - wanting. None of the book's reviewers discerned the highly selective composition of the political viewpoints arrayed by Trilling, though in such selection lies the crux of any novel of ideas. The few critics who detected that the novel was rooted in postwar liberal culture as much as the situation of the 1930s did so with vague allusions to "the age" rather than to the altered political alignments of Trilling's circle. ${ }^{5}$

It is revealing in and of itself that Trilling chose a full-length work of fiction rather than his perfected form, the essay, by which to express his views on the revolutionary experience of the $1930 \mathrm{~s}^{6}{ }^{6}$ The imaginary world of the novel permitted Trilling to control his portrait fully, free from the encumbrances that the writer of history or autobiography faces. Set around 1939 or

165 (18 Oct. 1947), 413-416; "Soul-Searcher," Time 50 (20 Oct. 1947), 106-109; J.M. Lalley, "Two Journeys and a Pastoral," New Yorker 23 (25 Oct. 1947), 126-132; George Mayberry, Untitled Review, New Republic 117 (13 Oct. 1947), 29; Lloyd Morris, "Ideas and Intellectuals in Close Conflict," New York Herald Tribune Weekly Book Review (12 Oct. 1947), 4; Henry Rago, Untitled Review, Commonweal 47 (14 Nov. 1947), 121-122; Richard A. Cordell, "Clash of Ideas," Saturday Review of Literature 30 (11 Oct. 1947), 25.

5 . The literary scholarship on the novel, some of it quite fine, has tended to reproduce this tendency. Most consider The Middle of the Journey from a purely formal standpoint, usually by tracing in it the influence of E.M. Forster, Henry James, and, sometimes, Thomas Mann. While Trilling is often held up as the consummate man of letters, some have denigrated his novel as the sort of fiction an English professor would write: emotionally bloodless, with shallow characters, too much devoted to ideas. For an exemplary aesthetic criticism of the novel, see Irving Howe, "On The Middle of the Journey," New York Times Book Review (22 Aug. 1976), 31.

Remarkably, none of the full-length studies of Trilling's work, even those which emphasize liberalism as a theme in The Middle of the Journey, passes beyond such formal criticism to situate the work within the cultural and political evolution of the New York intellectuals. A surprising number of the book-length biographies and political criticisms of Trilling overlook The Middle of the Journey altogether. Diana Trilling rightly considers the novel to have been unduly neglected in critical assessments of her husband's life. The most famous assessment of the conservative implications of Trilling's liberalism, Joseph Frank's "Lionel Trilling and the Conservative Imagination" (1956), made no mention of The Middle of the Journey, nor did Frank's 1978 retrospective on that essay. The chief exception to the general neglect of The Middle of the Journey as a signpost along the road taken by the New York intellectuals is the brief, well-taken treatment by Alan Wald in his collective study of Trilling's circle. Mark Shechner's After the Revolution sensitively places Trilling within a Jewish-American literary and psychoanalytic tradition and treats The Middle of the Journey as integral to the Trilling corpus. See: Diana Trilling, The Beginning of the Journey (New York 1993), 368-369; Joseph Frank, The Widening Gyre (New Brunswick: 1963); Joseph Frank, "Appendix (January 1978)," Salmagundi 41 (Spring 1978), 46-54; Alan Wald, The New York Intellectuals (Chapel Hill 1987); Mark Shechner, After the Revolution.

6 Alan Wald has observed that in none of Trilling's political and cultural essays did he confront the radicalism of the thirties as directly as in The Middle of the Journey. (The New York Intellectuals, 243). 
1940 - just after the Moscow trials and before the Second World War - the plot of The Middle of the Journey unfolds within a single New England summer. Only the main character's ruminations about his earlier illness and recuperation in New York diverge from the setting of the Connecticut countryside. The novel's location and mood, therefore, is distant from the New York political and literary scene that is its ultimate object. That suited Trilling's purposes well, for it enabled him to contrast the intellectual tendencies of his day discretely, at a calm remove. Trilling's characters are ideal types that embody significant middle-class intellectual currents of the mid1930s. Isolated in a pastoral location, they are able to engage in high-level philosophical conversation, personal soul-searching and piercing assessments of one another, uninterrupted and unimpeded by the intrusions and complications of city life. The radical predilections of intellectuals in the late 1930s, the setting suggests, are most easily understood and exposed as inadequate and misguided when they are uprooted and removed from the masses of workers, political organizations, and social forces that gave them impetus in the first place. That fictional device betrays the built environment necessary to sustain the plausibility and attractiveness of Trilling's preferred standpoint, which he proposes wistfully, even regretfully, in the end: a resigned middleclass individualism defined by a pragmatic disposition, both relentlessly intellectual and indifferent to reaction and radicalism. ${ }^{\text {? }}$

7 Comparable, though ultimately different, points are made by critics Mark Shechner and Leslie Fiedler, for whom the novel's remove from Trilling's personal experience reveals its weakness. To Shechner, Laskell's sickbed conversion is implausible because it occurs "without the benefit of Trilling"s vital experiences, that is to say, his years spent in the library." Yet Shechner also, somewhat contradictorily, believes that Connecticut serves as a metaphor for the seminar room, and that Trilling's fictional emphasis upon abstract, colliding ideas "may argue the importance of ideas to history, but it tells us nothing about the pressure of history upon ideas." Shechner thus simultaneously holds Trilling at fault for not drawing upon his scholarly experience and at fault for an overly scholastic conception of mental life. Fiedler, for his part, argues that by making John Laskell "both genteel and Gentile," Trilling fails: "I do not know whether Trilling lacks vitality because of his failure to tap his own Jewish sources, or whether he fails to tap those sources because of an initial lack of vitality; but somewhere here there is a clue to his failure, a failure whose outward symbol is the lack of Jewish protagonists in a novel by a Jew about an experience deeply rooted in Jewish life." Since Fiedler approached The Middle of the Journey in search of "The Jew in the American Novel," his disappointment was inevitable. The New York intellectuals' evolution, in any event, is only in part explicable by recourse to Jewish ethnicity. because a number of them (Dwight Macdonald, James T. Farrell and Edmund Wilson, for example, each of whom was more prominent in the thirties than Trilling) were not Jewish at all. Even among the Jews in the New York group, Jewishness was only a heavy focus of intellectual attention for a few of them, notably Elliott Cohen, Irving Howe and Alfred Kazin. Since Trilling's literary interests always centered upon the English tradition in letters, his novel's disregard for the particular experience of Jewish intellectuals, while noteworthy, is not as significant a contrivance as the novel's transposition of the political tensions of the 
At the time he wrote The Middle of the Journey, Trilling was an associate professor of literature at Columbia University and the author of books on Matthew Arnold and E.M. Forster. His mastery of literary form helped him to skillfully tease out the consequences and unintended implications of varied political beliefs in the lives of his characters. The story is deft, subtle and complex, its figures multifaceted, contradictory and sympathetically sketched. Trilling is sensitive to the varieties of personal consciousness and emotional experience, and his use of symbols and allegory, while suggestive and frequent, is almost never obvious or didactic. These traits, though admirable, present a paradox. For while Trilling explores modernism and Marxism from a critical standpoint - often in a manner that presages his protagonist's disillusionment with outworn ideologies and turn toward a skeptical, realistic liberalism - he is at the same time implicitly beholden to the methods and insights of Freud and Marx. That contradictory sensibility, not just the novel's politics in the more conventional sense, makes The Middle of the Journey emblematic of the mood of the New York intellectuals in the post-war years. The New York retreat from Marxism and cultural radicalism was often expressed and carried out with language and ideas derived from those very traditions.

The key motifs of Trilling's novel began with its title. Prominent among its multiple meanings was the timeless allegory of life as a journey, an allusion that may well have been drawn from the opening lines of Dante's Inferno: "In the middle of the journey of our life, I came to myself in a dark wood, where the direct way was lost." John Laskell, the protagonist of The Middle of the Journey, undergoes a dramatic, purgatorial, mid-life shift in values and allegiances. The about-face is so sharp that it cuts to the quick of Laskell's understandings of his friends and his conception of purpose. This joining of politics and life, belief and biography, is underscored by Laskell's mental reconciliation to the certainty of death after an illness befalls him. Death is an eventuality that Laskell's "progressive" - the word is important, with its temporal implications of movement and improvement, of ascent to perfection - friends are unwilling to accept or even to acknowledge. The title's reference to journey gives The Middle of the Journey a second, related connotation deriving from the term "fellow-traveler," the commonplace term for left-leaning liberals who were willing to collaborate with, though not join, the Communist Party during the Popular Front. Until the fateful summer of

thirties from the city to a small rural community. While many of the New York intellectuals spent their summers in Connecticut and Vermont, the main source and object of their intellectual and political energy was New York, so that the isolation of their radical aspirations in that setting was bound to make them appear willfully unrealistic. See: Shechner, After the Revolution, 80-1; Leslie Fiedler, To the Gentiles (New York: 1971), 114. 
the narrative, Laskell was one such liberal, as are his friends, Arthur and Nancy Croom. In the middle of his journey alongside Communism, however, he wanders from the path, eventually selecting a less certain destination than that pursued by his companions. Finally, there is the simple, literal meaning of The Middle of the Journey, for the novel begins with Laskell's arrival at the train station in the small town of Crannock and ends with his departure on a returning train to New York. The plot transpires between those trips - hence, in the middle of Laskell's journey. Even here, however, the seemingly straightforward is overlaid with allegory, for Laskell is joined on his journey to the country by Gifford Maxim, a Communist in the throes of crisis, and when Laskell departs it is in solitude, leaving behind on the platform his fellow-traveling friends, the Crooms. The real journey and teh political journey coalesce.

The first sign of the change in Laskell's life, the germinal moment of his new disposition, is equally infused with symbolism. The event - which occurs just before his decision to visit the country and is recalled in the narrative retrospectively - unfolds when Laskell awakes from a delirium to find himself disoriented and under quarantine in his New York apartment. At his bedside is Miss Paine, a nurse, who explains that he has contracted, at age 33, scarlet fever - clearly an allegory for revolutionary enchantment. He learns from his physician, Dr. Graf, that the morbidity had been nearly fatal, lending the aura of a classic deathbed conversion to his impending mental transformation. Laskell's initial sensation of renewal upon awaking has a quasi-mystical quality to it: "His pleasure was not in being ill but in being well, his wonderful clarity, in his sense of lightness and grace, his feeling of perfect order."(41) There is even plainer indication that Laskell has started anew when the doctor tells him that he will soon shed his skin. "You'll be as soft as a newborn babe!" declares Paine, lest the point be lost.(62)

Laskell's new lease on life takes form in consciousness as well as body. In the course of his illness, confined to his bed, Laskell acquires a fresh sensibility mediated through his thinking about his nurses and a flower. Paine, Laskell soon discovers, is the evening nurse. She is supplemented by Miss Debry, the day nurse. The two are as different as the times of their watch. Debry is Canadian, irritating, full of incessant chatter, obtuse, yet sensual and willing, her very presence suffused with sexual invitation. Paine, by contrast, is British, quiet, restorative, witty, perceptive, orderly, unattractive and directive. Meanwhile, Laskell begins to muse upon a single rose that has outlived the others he was sent. The rose is neither red nor yellow - colors that are often taken to stand for radicalism and cowardice - but "a strange new tone, a flushed and dusky pink, tawny and bronze." He regards the autumnal hues of the rose for such long spells and with such intensity that Paine exclaims, to his delight, "You seem to be having quite a love affair with that flower!"(59) 
Only later, after reflection, does Laskell admit, "I think it was death I was in love with."(221) Soon Dr. Graf informs Laskell that he is well enough to permit one nurse to go, and Laskell makes a point of selecting Paine, against the usual practice of retaining the day nurse. Eventually, however, Laskell must also let Paine go, for he has regained sufficient strength and her business with him is done. The rose, too, wilts. Laskell rises from his sickbed a new man with a new skin. Having accepted pain over pleasure by selecting Paine instead of Debry, having recognized death and ambiguity in his admiration for the tawny rose, Laskell has in effect understood subconsciously that he must move beyond both pain and death to confront life. ${ }^{8}$

His initial sensation of wholeness upon regaining consciousness after his fever contrasts with the panic Laskell feels after he debarks from the train in New England. He has traveled to visit his friends, the Crooms, and convalesce in the countryside. But Laskell is shocked to find that no one has come to meet him. He is completely alone, having left Maxim, his traveling companion, behind at the Westport station. When neither the Crooms nor their helper meet him at the platform, Laskell is consumed by a feeling of terror. He finds this profound sense of terror, brought on by unexpected solitude, inexplicable. That Laskell's overpowering fear of being alone at that moment is highly significant is clear at the end of the novel, when he is filled with a sense of relief and serenity at the very moment when he takes leave of his old friends at the same station. Then, alone in his passenger seat, leaving the Crooms behind on the platform, Laskell is reconciled at last to individuality and selfreliance.

Between his arrival and departure in Connecticut, that is to say, Laskell's transformation is completed. His comprehension of death, reached in the course of his illness, brings him reluctantly and unsteadily to a new worldview that only congeals as he spends the summer contemplating the politics of left and right represented in his friends' philosophies of death, modernity and the future. At the time of his arrival, Laskell is still a "sincere liberal," politically aligned with the left despite his changed psychology. While unattached to any radical party, he is unwilling to criticize revolutionary politics for lack of a viable alternative. A graduate of Columbia, he has contributed to technical journals and liberal magazines, has written a book, Theories of Housing, and is working on a new book on the planning of cities in antiquity, a subject

8 Many of the elements of this portion of the novel are, according to his widow's memoir, drawn from Trilling's own bout with scarlet fever in 1928, during which confinement his wife sent him a dozen Talisman roses. This autobiographical connection, however, is transcended by the highly symbolic function of the episode in the novel. Diana Trilling, The Beginning of the Journey, 16. 
perhaps selected by Trilling to underscore the mutual affection for technocratic planning held by liberals and Communists in the 1930s: "He had committed himself to the most hopeful and progressive aspects of modern life, planning their image in public housing developments, defending them in long dull meetings of liberals and radicals."(28-29) Boredom, thus, is combined with hope in Laskell's experience of progressive liberalism. So is depression with resignation:

There were days when he was meaninglessly depressed, when there seemed no point to his busy life. Such days had been frequent in Laskell's youth. They had seemed proper to the literary temperament. They did not seem proper to the life of useful activity he now led. But they always passed and Laskell did not attach much significance to them. He understood that they were part of the difficulty of being a modern man. It was a difficulty he heard much discussed among his friends.(37-38)

Because Trilling creates a persistent association of this sort between modernity, planning, the future and progressive politics, Laskell's subconscious apprehension from his sickbed of the reality of death becomes the pivot around which his political worldview begins to rotate. When he arrives at the summer home of Arthur and Nancy Croom, who have been his closest friends for some time, they are curiously unwilling to discuss his mortality, the very subject most on his mind. Like Laskell, Arthur and Nancy are young professionals and fellow-travelers, even closer than he is to the Party. They change the topic of conversation quickly rather than confront Laskell's condition. Nancy is unable even to say the word "death," breaking off in mid-sentence whenever she refers to it. When Laskell eventually calls her on the point, he makes the connection explicit: "You talk about morbidity and living in the past - as if you thought that death was politically reactionary."(125) Earlier, during his love affair with the rose, Laskell reflected that his friends would call it a "mechanism of escape," a pleasant illusion, but it dawns on him in examining his awkward new relations with the Crooms that the true escape is that form of willed political activity which refuses to account for the ineluctability of death and gives itself up to the future.

It is evident from the outset that the Crooms' mental repression of death is bound up with their philosophical and political conception of the relationship between present and future. That view, in which the present is justified insofar as it helps to bring "reality" into being, burns most brightly in the example of Gifford Maxim. Unique among the principal characters in being referred to almost exclusively by his last name, Maxim is a mutual acquaintance of Laskell and the Crooms whose name evokes several meanings. It is, first, two letters removed from Marxism. The full name Gifford Maxim, 
moreover, has a Russian ring to it and is, indeed, a virtual inversion of the name of Maxim Gorky, the Russian novelist who both collaborated with and crossed swords with Stalinism. ${ }^{9}$ While the Crooms are devotees of the "near future," Maxim is described as "the man of the far future, the bloody, moral, apocalyptic future that was sure to come."(61) In his mind's eye, Laskell tends to visualize Maxim flanked by two great figures, implacable power and the morality of the oppressed, while surrounded by great corridors that contain the "infinite dim vistas of History, which was not the past but the future."(133) Though Laskell does not embrace Maxim's ideas or organization, he initially shares a similar orientation toward the future:

It was established that Laskell accepted Maxim's extreme commitment to the future. It was understood between them that Laskell did not accept all of Maxim's ideas. At the same time, Laskell did not oppose Maxim's ideas. One could not oppose them without being illiberal, even reactionary. One would have to have something better to offer and Laskell had nothing better.(128)

Maxim was thus the embodiment of an integral link between Communism, liberalism and the future, probably derived by Trilling from such remarks as the famous one of muckraker Lincoln Steffens, who in the early 1930s vowed that he had "seen the future and it works" when he returned from a trip to the Soviet Union.

Laskell's sense of certainty in the future is shattered in the immediate aftermath of his illness, when Maxim appears on his doorstep a broken man.

9 Maxim Gorky (1868-1936), a realist writer, was a Bolshevik early in the century and the author of Mother (1906). In 1917, he was sharply critical of the Bolsheviks, though he subsequently expressed admiration for Lenin and Trotsky. He removed himself to Italy for much of the 1920s before he was persuaded to return in 1928 to the Soviet Union, where he was provided with two mansions and became a spokesman for "socialist realism." Many scholars believe that his sudden, mysterious death in 1936 was arranged by Stalin when Gorky urged reconciliation with the Left and Right Oppositions and opposed the purges. The historical Maxim Gorky, in other words, was variously an accomplice, critic and victim of Stalinism, much like Trilling's fictional Gifford Maxim.

There is another possible derivation of the name. In the definitive biography of Trilling's friend and neighbor Reinhold Niebuhr (1892-1971), Richard Fox suggests that the name of Gifford Maxim in The Middle of the Journey might have been a reference to "maxims of the Gifford lectures," which Niebuhr had delivered shortly before Trilling's novel was written. Although Maxim's abandonment of Marxism for a hardbitten Christianity squares with Niebuhr's course, however, the kind of realism adopted by Laskell is actually much closer to Niehbur's later sensibility than to Maxim's stormy, millenarian religiosity. Fox acknowledges that the primary model for the character was Chambers. See Richard Fox, Reinhold Niebuhr (San Francisco 1987), 234. 
Maxim, revealing that he has just broken from the Party to which he had given his life, is nervous and distraught. He confides to Laskell that he had not merely had a change of heart, as ordinary Party members often did, that would permit him to quietly drop away. His work for the Party had been "special and secret," so special and secret that now he feared for his life because he knew too much. Laskell is overcome with disbelief. Like other fair-minded liberals, he had considered stories about the Party's capacity for skullduggery, terror and lies to be nothing more than a concoction of reactionaries. Unable to grasp Maxim's fear of harm at the hands of the Party, he is first filled with revulsion and then wonders whether Maxim is insane; the reaction is replicated by the Crooms when they first hear the news of Maxim's turn. The hold of ideology on the mind, Trilling means to convey, is stubborn.

Even after abandoning the Party, Maxim personifies the bleakest features of Communism in the Stalin era. He is inquisitorial and manipulative in his method of obtaining information, shrewdly devoted to "results" rather than "ideals," and the articulator of an elitist and technocratic interpretation of Lenin's conception of revolutionaries as professionals. Ruthlessly - and needlessly, given Laskell's recent brush with fate - Maxim pulls out a picture of Elizabeth Fuess, Laskell's dead lover, as if to remind Laskell that death does occur. He appeals to Laskell to help him establish an "existence" as an editor of Kermit Simpson's liberal weekly, The New Era. By making his new life outside the Party a public fact in whatever way possible, Maxim hopes to bring to an end his underground status and make his assassination all the more difficult.

Laskell assists him in his request. But after reading Maxim's first essay for The New Era, a contrived review of what Laskell later learns is a non-existent edition of Herman Melville's novel Billy Budd, Laskell understands that Maxim has not simply become a divergent progressive, discouraged about the Party yet still committed in some fashion to the future. Maxim has replaced devotion to the future with a mystical religiosity, revolution with the starkest reaction. When the Crooms read the same essay, to Laskell's surprise, they find comfort in Maxim's emphasis on law and necessity, which to them seems harmonious with their philosophical justification of the Soviet Union as progressive, if imperfect. This unexpected convergence of Maxim and the Crooms introduces a new theme into The Middle of the Journey - an affinity between revolution and reaction, between dedication of life to the future and dedication of life to the past. Although Maxim serves as a reality check, one who has seen the future and knows it does not work, he retains the fervent drives and shady mannerisms that he had cultivated as a devoted Party activist, so he has lost none of his essential ideological appeal for the Crooms.

The basic unity of left and right that Trilling wishes to underscore is brought to a climax in the discussion of responsibility which transpires in the 
novel's last pages. Ever since arriving in the country, Laskell has been at odds with the Crooms in their assessment of Duck Caldwell, their handyman. Duck was, first of all, late to pick up Laskell at the train station, and so he is unhappily associated in Laskell's mind with his experience of solitary terror. Duck's grandfather had been a senator and excessively rich, but his father was profligate and squandered the fortune, and Duck for his part is a habitual drunk. These facets of Duck's life, in combination with his handiwork, only make the Crooms praise Duck as the embodiment of an unvarnished nature, as "real." Laskell, unenamored, wonders why Duck is exempt from the general progressive effort to elevate consciousness. Laskell is attracted instead to Duck's wife, Emily Caldwell, to whom he eventually is drawn to make love with by the river. The Crooms, Nancy especially, reject Emily as affected, foolish and pretentious. Emily is indeed silly, drawing from Oswald Spengler's oracular and pessimistic Decline of the West the simple message of carpe diem, which she translates as "snatch the moment." But her innocence, affection for ideas several decades old, pretensions in her pottery to a "modern" design, honesty and radiant beauty also give her a certain charm, and supporting an interpretation of Emily as symbolic of the bygone, outdated intellectual life of the teens and twenties, the liberatory exuberance of the lyrical left. Too much stands between Laskell and Emily; their temporary attraction, while genuine, cannot hold..$^{10}$

Laskell has a less complicated affection for the Caldwells' young daughter, Susan, and he helps her prepare for a recital in the church variety show. Susan had selected the famous poem by William Blake which speaks of "dark Satanic mills" and promises no rest "Till we have built Jerusalem in England's green and pleasant land." At the performance, Susan stammers during her recitation and manages to finish only when prompted by Laskell. Descending from the stage, she is confronted by her father, Duck, who is drunk and slaps her twice for her error. Unbeknownst to Duck, Susan suffers from a frail heart. She dies instantly, from the shock rather than the force of the blows. When Duck hit Susan, thus, "reality" in effect kills the youthful hope for the future, the innocent herald of Jerusalem. That explains why it is that Nancy, who never showed any emotion for the child when she was alive, is the most affected of all by Susan's death.

10 Though described in the third person, Laskell is in many ways a stand-in for Trilling. The sexual liaison between Laskell and Emily is thus filled with implications that extend far beyond the dalliance with bohemianism that it clearly represents intellectually. That Laskell, an intellectual from New York, was able to make love to the wife of Duck, the embodiment of proletarian masculinity, is redolent with suggested significance. In that event - an act of possession, desire and affection combined - the characteristic mid-century cultural stereotype of American intellectuals as effeminate eggheads meets with resounding repudiation; it is almost as if the passion of Emily for Laskell were the ultimate intellectual's revenge. 
Subsequently, the ring of friends, Maxim included, enter into a debate over whether Duck was responsible for killing Susan. Arthur Croom attempts clumsily to explain Duck's actions in terms of his sociological circumstance and character formation, absolving him of blame. Maxim, summoning his new theological absolutism, maintains that total responsibility of the individual is necessary to any morality. In trying to strike a third course from his friends, Laskell first tests his new perspective openly. He attempts to transcend the dichotomy: "An absolute freedom from responsibility - that much of a child none of us can be. An absolute responsibility - that much of a divine or metaphysical essence none of us is."(333) Suddenly, it is apparent how far Laskell has traveled. The Crooms fault him for shilly-shallying, Maxim for unoriginality. "They were angry," writes Trilling. "He knew why they were angry at him. It was the anger of the masked will at the appearance of an idea in modulation." (334) This final standpoint, the appreciation of ideas in modulation, is presented as free of ideological encumbrance, of the dictates of the future and the past, of progress or reaction. It is the product of a new maturity, a growth out of childhood. Laskell had come to perceive "that the future and the present were one - that the present could no longer contrive and manufacture the future by throwing forward, in the form of expectation and hope, the desires of the present moment."(155)

His new view does not fill Laskell with complacency, however, for his friends, who hew to reactionary and progressive concepts of history, remain in sight. Laskell, having come to abjure History in the grand sense, conceives of the historic situation no longer as an anticipation of future reality, still less as a moment in a series of recurring cycles, but instead as a great pendulum. "Maxim," he deduces, "was riding the pendulum."(333) Here the novel is revealed to be a commentary on the late 1940s, when the ex-Communist reactionary was rising to prominence as a social type, just as much as a retrospective examination of the decade in which it is ostensibly set. This is the sort of quality that gives The Middle of the Journey the flavor of a roman a clef. It is, after all, a novel about the kind of people Trilling knew best: highly-educated professionals and intellectuals who normally reside in New York, are middleclass in origin, and are committed to the world of ideas. This slice of the radical populace is unable to stand as representative of the either the Marxist left, progressive liberalism or the Communist Party. It does, however, fit the profile of the archetypal New York intellectual who, like Laskell, was beginning to adopt a disappointed liberalism in the early or mid-1940s. Laskell's psychological odyssey is unique, but his final political mindset and reasons for rejecting Communism resonate with the politics advanced by Trilling and others grouped around Partisan Review in the 1940s. Like Laskell, the New York intellectuals forswore their earlier cultural and political radicalism for a new "realism." 
There is, however, a vacancy in the constellation of ideas featured by Trilling, one crucial to understanding the actual radical intellectual experience of the thirties: left-wing socialism. The only figure close to that strain of thought is Mr. Folger, an old farmer and chauffeur with whom Laskell rooms while staying in the country. Mr. Folger, writes Trilling, reads an "odd little paper got out by an isolated socialist group in Hartford" and grumbles about "the interests" and social injustice. Mr. Folger is a quirky but appealing fellow: "He had much eccentric dignity and a high manner. He carried irony very far, so far that he almost never communicated directly."(78) Mr. Folger's group admires William Morris and its language conjures up images of nineteenth-century workingmen. In some ways, the group is evocative of the Socialist Labor Party, by the 1930s an anachronistic sect neatly sealed off from contemporary politics and the passage of time, dutifully reproducing the writings of Daniel De Leon. Yet Mr. Folger is not a Marxist but a romantic anti-capitalist in the English cultural tradition Lionel Trilling knew so well. Laskell likes Mr. Folger very much, but his ideas - much like those of Emily - are quaint and unhelpful to serious deliberations on the present and the future. Mr. Folger, though more genial than Maxim and his ponderous religiosity, belongs equally to the past.

Entirely absent from Trilling's novel of ideas, thus, is that perspective which most influenced the New York intellectuals in the 1930s: contemporary revolutionary Marxism. All of the New York critics, Trilling included, were allied to one degree or another during that decade with the camp of revolutionary anti-Stalinist socialism, a current that had its most influential voice in the exiled Russian leader Leon Trotsky. The living example of Trotsky made a powerful impression on the minds of many young radicals in the 1930s: head of the Petrograd Soviet, comrade of Lenin, director of the Red Army, the Old Bolshevik who dared to oppose bureaucratic tyranny in the Soviet Union and penned brilliant refutations of Stalin's policies. While followers of Trotsky were at the gravitational center of the anti-Stalinist left in the 1930s, however, anti-Stalinist revolutionary socialism was by no means limited to them alone. The American Workers Party and, for a time, the Socialist Party did not take their cues from Trotsky but did advocate socialist revolution and criticized official Communism from a democratic working-class perspective, as did such independent, multi-tendencied journals as The Modern Monthly, The Marxist Quarterly and Partisan Review.

Such ideas were not merely in the air. Trilling himself had a political history in the 1930s closely bound up with the revolutionary socialist movement, though that association has been routinely misunderstood or obscured 
in the scholarly literature on his life and work. ${ }^{11}$ First won to the communist left by Sidney Hook, Trilling supported the Communist Party slate in 1932. Like Hook, Trilling became an anti-Stalinist soon afterward, and he signed the famous open letter of 1934 denouncing the CP's disruption of a Madison Square rally to honor the Austrian social democrats who died resisting the fascist seizure of power. "Neither Lionel nor I was ever a Trotskyist," writes Diana Trilling, "nor even much of a Trotskyist fellow traveler. But as between Stalin and Trotsky, we for a long time took the side of the latter." That somewhat understates the degree of affinity the Trillings had for Trotskyism in the 1930s, however. Both participated in the Non-Partisan Labor Defense, a civil liberties organization controlled by the Trotskyists. In 1936, Lionel Trilling was a member of the American Committee for the Defense of Leon Trotsky. He nearly lost his job at Columbia that same year because of prejudice against him as a Marxist and Jew. "In 1937," Diana Trilling elsewhere acknowledges, "Partisan Review began publication as an independent journal of Marxist opinion; that is, as a revolutionary journal independent of the Communist Party. Lionel was able to live comfortably with the revolutionary program of the new periodical. He appeared in its first issue and continued to be one of its contributors throughout its years as a Marxist publication."12

This dissident revolutionary tradition, so essential to the political education of the New York intellectuals, presented a challenge to liberalism far more serious and worthy than that posed by Stalinism. But it is absolutely

11 William M. Chace, for example, writes that Trilling "was never really a "radical." Chace takes Trilling's 1939 declaration in Partisan Review of his primary commitment as an intellectual to be evidence of a refusal to align himself with the working class by downplaying Trilling's affirmation in that very article of "the historic role of the working class and the validity of Marxism." Daniel T. O'Hara uses the term "Trotskyite" to refer to Trilling's Partisan Review politics, incognizant that "Trotskyite" was the derogatory epithet used by Stalinists and their sympathizers to refer to Trotskyists. Others ignore Trilling's antiStalinist radicalism of the mid-thirties: Stephen $\mathrm{L}$. Tanner treats it as ephemeral and superficial, and Edward Joseph Schoben, Jr., is attentive to the influence of Freud far more than Marx on Trilling. The most accurate summation of Trilling's politics in the 1930s is contained in Mark Krupnick's Lionel Trilling and the Fate of Cultural Criticism (1985). See: William M. Chace, Lionel Trilling: Criticism and Politics (Stanford 1980), 49-50; Daniel T. O'Hara, Lionel Trilling: The Work of Liberation (Madison 1988); Stephen L. Tanner, Lionel Trilling (Boston 1988); Edward Joseph Shoben, Jr. Lionel Trilling (New York 1981); Mark Krupnick, Lionel Trilling and the Fate of Cultural Criticism (Evanston 1985).

12 Diana Trilling, The Beginning of the Journey, 213, 221. 
missing from the imagined political world of The Middle of the Journey. The omission is far from trivial, and not only because the thirties as actually experienced by Lionel Trilling cannot be understood without mention of it. Laskell's dawning opposition to the doctrine and practice of Stalinism would not have required him to abandon the future if some more plausible rendering of the future had existed. The narrative's implicit equation of the Communist Party with Marxism and revolution would not have been as facile, either, because independent socialists in the 1930s considered Stalinism the abnegation, not the culmination, of Marx's project. Nor would the equation of conventional liberalism with Marxism have passed free from question, for left-wing socialists sharply contested the confusion of liberalism for radicalism by fellow travelers during the Popular Front of the 1930s. In other words, a much different conception of radical political life - one both revolutionary and democratic, solidaristic and critical, realistic and visionary, principled and flexible - might have been projected by a novel more reflective of the radical scene of the 1930s that Trilling himself experienced. ${ }^{13}$

It would be pointless, however, to complain that Trilling did not write a different book. That he wrote the book he did is precisely what matters. The Middle of the Journey illustrates how far the New York intellectuals of the mid-1940s had traveled from their politics of a decade before. Cold War liberalism was not, as the New York intellectuals liked to imagine, the logical extension of anti-Stalinist radicalism, but its reversal. Theirs was a highly constructed "realism." In order to sustain a disappointed reconciliation with liberalism and bourgeois society, they typically suppressed the memory of a democratic alternative to capitalism and spoke instead of the unpalatable choice between Communism and reaction. That Trilling's novel of the thirties was so designed, whether by conscious or unconscious repression of his own

13 Lest some policeman of culture for The New Criterion stumble upon these lines, a delineation of method is in order. Literature should not be measured by a narrowly political yardstick. At the same time, a novel of ideas, especially a novel of political ideas, cannot escape scrutiny of the political representations it makes. The point is not that had Trilling included revolutionary socialism (a challenge to his disappointed liberalism far more serious than the alternatives he did include) his novel would necessarily have been a better one. It might well have been worse. Nor would that inclusion have provided an automatic solution to the moral and psychological dilemmas Trilling explored in The Middle of the Journey. As anyone who has attempted to negotiate the world as a revolutionary knows, the revolutionary experience is subject to moral and psychological predicaments every bit as severe as those undergone by Laskell. The admission of a revolutionary perspective into Trilling's cast of ideas would only have opened the way for a new set of dilemmas and complexities. The question of whether the moral disposition toward life and how to live it settled upon by Laskell could be accommodated within a mind still committed to revolutionary aims, for example, is one not easily answered, whether one way or the other, and would therefore provide ample fodder for new fictional explorations. 
political background, shows how the history of the New York intellectuals was less the one of their own imagination, a journey that brought wise maturation and fresh realism, and more the creation of a new ideology, one that identified sophistication and wisdom with a tragic resignation to the social horizons of the present.

This article is dedicated to the memory and honor of Christopher Lasch (1932-1994). Insightful criticism and suggestions from Casey Blake, Ned Hodgeman, John Roche, Alan Wald and the anonymous reviewers for left history improved this essay greatly. 